\title{
Laveineopteris polymorpha FROM THE LOWER WESTPHALIAN (LANGSETTIAN) "FERN LEDGES" AT SAINT JOHN, NEW BRUNSWICK, CANADA, AND COMPARISON WITH Laveineopteris hollandica FROM EUROPE
}

\author{
Robert H. WAGNER \\ Centro Paleobotánico, Jardín Botánico de Córdoba, Avda. de Linneo, s/n, \\ 14004 Córdoba, Spain; e-mail: cr1wagro@uco.es
}

Wagner, R. H. 2008. Laveineopteris polymorpha from the lower Westphalian (Langsettian) "Fern Ledges" at Saint John, New Brunswick, Canada, and comparison with Laveineopteris hollandica from Europe. [Laveineopteris polymorpha del Westfaliense inferior (Langsettiense) de los "Fern Ledges" de Saint John, Nueva Brunswick, Canadá, y su comparación con Laveineopteris hollandica de Europa.] Revista Española de Paleontología, 23 (2), 139-156. ISSN 0213-6937.

\begin{abstract}
A documentation is presented of the pteridosperm (?) foliage species Laveineopteris polymorpha (Dawson, 1862) comb. nov. from its type locality at Saint John, New Brunswick. This Canadian species is also present in the United States and in the British Isles. The similar species Laveineopteris hollandica (Stockmans, 1933) Cleal \& Shute, 1995, of European provenance, is discussed for detailed comparison. Lists of synonymy are provided for both species. These are commented on in detail. The stratigraphic and geographic distribution of these two species is discussed as well.
\end{abstract}

Keywords: Laveineopteris, Neuropteris, Langsettian, North America, Europe.

\section{RESUMEN}

Se presenta nueva documentación referente a la parte vegetativa de la probable pteridosperma Laveineopteris polymorpha (Dawson, 1862) comb. nov. obtenida a partir de material de su localidad tipo en Saint John, Nueva Brunswick. Esta especie canadiense se encuentra también en Estados Unidos y en las Islas Británicas. Es bastante parecida a Laveineopteris hollandica (Stockmans, 1933) Cleal \& Shute, 1995, descrita en Europa. Se enumeran en extenso las listas de sinonimia de ambas especies y se analizan en detalle. Asimismo, se comentan las distribuciones estratigráficas y geográficas de las dos especies.

Palabras clave: Laveineopteris, Neuropteris, Langsettiense, Norteamérica, Europa.

\section{INTRODUCTION}

A general revision of the lower Westphalian floras of the Maritime Provinces of Canada, undertaken on behalf of the Geological Survey of Canada with the support of local organisations such as the New Brunswick Museum, has confirmed that these floras are closely similar to those present in western Europa, even to a larger extent than the published lists suggest. This refers particularly to the British Isles. It emphasises the close links between these two areas at a time when the Atlantic Ocean had not yet opened up. Whereas in several cases certain species described from Canada proved to be identical with European taxa described earlier, the reverse is also true, as Stopes $(1914,1917)$ has already pointed out. These involve taxa introduced in the mid 1800s by Dawson. Some of these taxa were poorly documented and superseded, in practice, by better described species based on more adequate material from Europe. Stopes (op. cit.) pointed out a few synonymies where Dawson's species enjoyed priority, but should be allowed to lapse in favour of the better known species from Europe.

In other cases, Canadian taxa described by Dawson were either assigned improperly to European species or simply ignored, in view of the poor quality of illustrations and fragmentary nature of the specimens recorded by Daw- 
son. Some of these taxa should be reconsidered, particularly where museum collections allow a better perception of specific characters. A case in point is Neuropteris polymorpha Dawson, 1862. This species was introduced on quite fragmentary remains which were illustrated by very diagrammatic drawings. However, a later publication by Dawson (1871) showed a more complete specimen from the type locality at Saint John, New Brunswick. Although the illustration by Dawson (1871) was another diagrammatic drawing, this specimen was refigured photographically by Stopes $(1914,1917)$. This made it possible to identify the characters of Dawson's species. Unfortunately, Stopes (1914) synonymised Neuropteris polymorpha with Neuropteris heterophylla Brongniart, 1822, apparently in error. Later authors either ignored Neuropteris polymorpha, or swallowed it up in the synonymy of different species (see Bell, 1944: 81).

A revision of the large collection of "Fern Ledges" material in the New Brunswick Museum at Saint John has allowed the range of morphological variation of this fernlike foliage species to be established. This probable pteridosperm species appears quite similar to Laveineopteris hollandica, whilst being different to Neuropteris heterophylla auctorum (non Brongniart). Laveineopteris hollandica is a relatively uncommon species in the European area where it has been figured and described most exhaustively by Laveine (1967). Laveineopteris polymorpha and Laveineopteris hollandica are commented on in the present paper, with the aim to assess the characters of both. Only Laveineopteris polymorpha is figured here.

Class CYCADOPSIDA Barnard \& Long, 1975 Order TRIGONOCARPALES Seward, 1917, emend. Meyen 1984

Family Trigonocarpaceae Seward, 1917, emend. Meyen, 1984

Genus Laveineopteris Cleal, Shute \& Zodrow, 1990, emend. Laveine, 2005

\section{Laveineopteris polymorpha (Dawson, 1862) comb. nov.}

Figs $1-7 \mathrm{e}$

* 1862 Neuropteris polymorpha Dawson, p. 320, pl. XV, figs 36a-g.

* 1868 Neuropteris polymorpha Dawson - Dawson, p. 548, fig. 192c (copy of Dawson, 1862: pl. XV, fig. 36a), p. 549.

1871 Neuropteris polymorpha Dawson - Dawson, p. 49, pl. XVIII, fig. 212 (specimen illustrated photographically by Stopes, 1914).

? 1882 Cardiopteris Eriana Dawson, p. 114, Fig. IV.

1888 Neuropteris polymorpha Dawson - Dawson, p. 72, fig. 22c (fide Stopes, 1914: 58).

? 1893 Neuropteris Blissii Lesquereux - Kidston, p. 329-330, pl. I, figs 3, 3a (specimen figured photographically by Crookall, 1959: pl. XXXIX, fig. 4).
1910 Neuropteris polymorpha Dawson - Matthew, p. 248 (listed only).

p 1914 Neuropteris heterophylla Brongniart - Stopes, p. 58-61, pl. XIV, fig. 35 (photographic reproduction of specimen figured as Neuropteris polymorpha by Dawson, 1871: pl. XVIII, fig. 212); pl. XXI, fig. 56 (as Neuropteris sp. in plate explanation; attributed to Neuropteris loshii Brongniart, 1828a by Laveine, 1967: 145); non pl. XV, fig. 36 (specimen from Valenciennes, France, identified as Neuropteris loshii by Laveine, 1967); non pl. XV, fig. 38 [= Neuropteris obliqua (Brongniart, 1834) Göppert, 1846 acc. to Laveine, 1967].

? p 1914 Neuropteris eriana (Dawson) Stopes, p. 61-62, textfig. 11 (copy of Dawson, 1882: Fig. IV); non pl. XV, fig. 39 (probably a cyclopteroid pinnule of Paripteris).

1914 Neuropteris plicata Sternberg - Arber, p. 386, 387, 391, pl. 27, figs 10-11 (referred, with doubt, to Neuropteris cf. hollandica by Laveine, 1967: 161).

1922 Neuropteris rytoniana Kidston, p. 134 (nomen nudum) (see Crookall, 1959).

1933 Neuropteris microphylla Brongniart - Crookall, p. 58, pl. V, fig. 13.

1937 Neuropteris sp. (cf. latenervosa Jongmans) - Jongmans, p. 408, pl. 28, figs 81-83, pl. 29, figs 84,84 a.

* 1949 Neuropteris saginawensis Arnold, p. 192-193, pl. XXI, figs 1-2, 5-6 (referred to Neuropteris hollandica by Laveine, 1967).

p 1949 Neuropteris obliqua (Brongniart) Zeiller (sic) - Arnold, pl. XXIII, fig. 1; non p. 196-197, pl. XXIII, figs 2-4 (= Neuropteris obliqua).

1959 Neuropteris rytoniana Kidston ex Crookall, p. 113-114, text-figs 63A-C, pl. LII, figs 3-4, pl. LIV, fig. 1 (referred to Neuropteris hollandica by Laveine, 1967).

? p 1959 Neuropteris Blissi Lesquereux - Crookall, p. 127-129, text-fig. 65H, pl. XXXIX, figs 2-4; non pl. XLIX, figs 1-2 (aff. Neuropteris blissii Lesquereux, 1884); non text-fig. 45 (= Neuropteris blissii - type); non text-fig. 65C (aff. Neuropteris blissii).

? 1959 Neuropteris thymifolia Sternberg-Crookall, pl. XLVII, figs $1-3$.

? 1997 Neuropteris hollandica Stockmans - Blake, p. 76 (chart).

? 2007 Laveineopteris loshii (Brongniart) - Falcon-Lang \& Miller, p. 247.

* - type; p - pars; ? doubtful.

Lectotype: Specimen figured by Dawson, 1862, pl. XV, fig. 36a (see Fig. 1a of present paper). According to the Catalogue of type and figured fossils in the Redpath Museum, McGill University, Montreal (Alison \& Carroll, 1972: 129), the specimen numbered 12,237 would be the holotype. This may be the specimen from which Dawson (1862: pl. XV, figs 36a-g) figured several pinna fragments. Perhaps, the most significant among these fragments is the apical part of a penultimate pinna figured as 36a. This was selected for refiguration by Dawson, 1868, and may be regarded as the lectotype. Similar pinnae appear in the terminal part of a pinna of the penultimate order which was figured by Dawson, 1871, pl. XVIII, fig. 212, refigured here (Figs $1 b, 2-3)$. This specimen is mentioned as a plesiotype by Alison \& Carroll (1972). 
Material: The New Brunswick Museum collection contains several pinna fragments from the "Fern Ledges" at Saint John, including fragments of pinnae of the penultimate order. All remains are impressions on slaty shale, dark grey in colour (Figs 4-7). Additionally, the specimen figured by Dawson (1871: pl. XVIII, fig. 212) has been examined in the Redpath Museum, Montreal (see Figs 2-3). All the specimens figured by Dawson (1862, 1871) are from the Hartt Collection, and originate from the "Fern Ledges", Carleton Township, Saint John (R.F. Miller, pers. comm., 31-03-2008).

Description: Terminal of penultimate order slender, with well individualised apical pinnule which is bluntly acuminate. Rachis thin. Ultimate pinnae terminals also slender with bluntly acuminate apical pinnules which are variable in size, depending on the location of the pinna; in fully developed pinnae they are not much bigger than the lateral pinnules. Pinna terminals are relatively larger in the small pinnae occurring in the upper part of penultimate pinnae. Pinnules extremely variable in size depending on position in the frond. Pinnae with large, acuminate pinnules and a slightly broader rachis presumably occur in lower part of the frond (Fig. 5e). Other pinnae show ovoid pinnules, twice to three times as long as they are wide, with bluntly acuminate apices, whilst pinnae with shorter, more rounded pinnules also occur. Pinnule bases usually rounded on both sides, but a wider insertion with partial fusion of pinnule base to rachis occurs in near-terminal pinnules. Lamina apparently rather thin, non-vaulted, with thin midrib well marked but not sunken into pinnule limb to a significant degree (however, the slaty condition of the shales carrying the imprints aids in producing a flattened appearance). Midrib thin, extending commonly up to one half the pinnule length and less commonly up


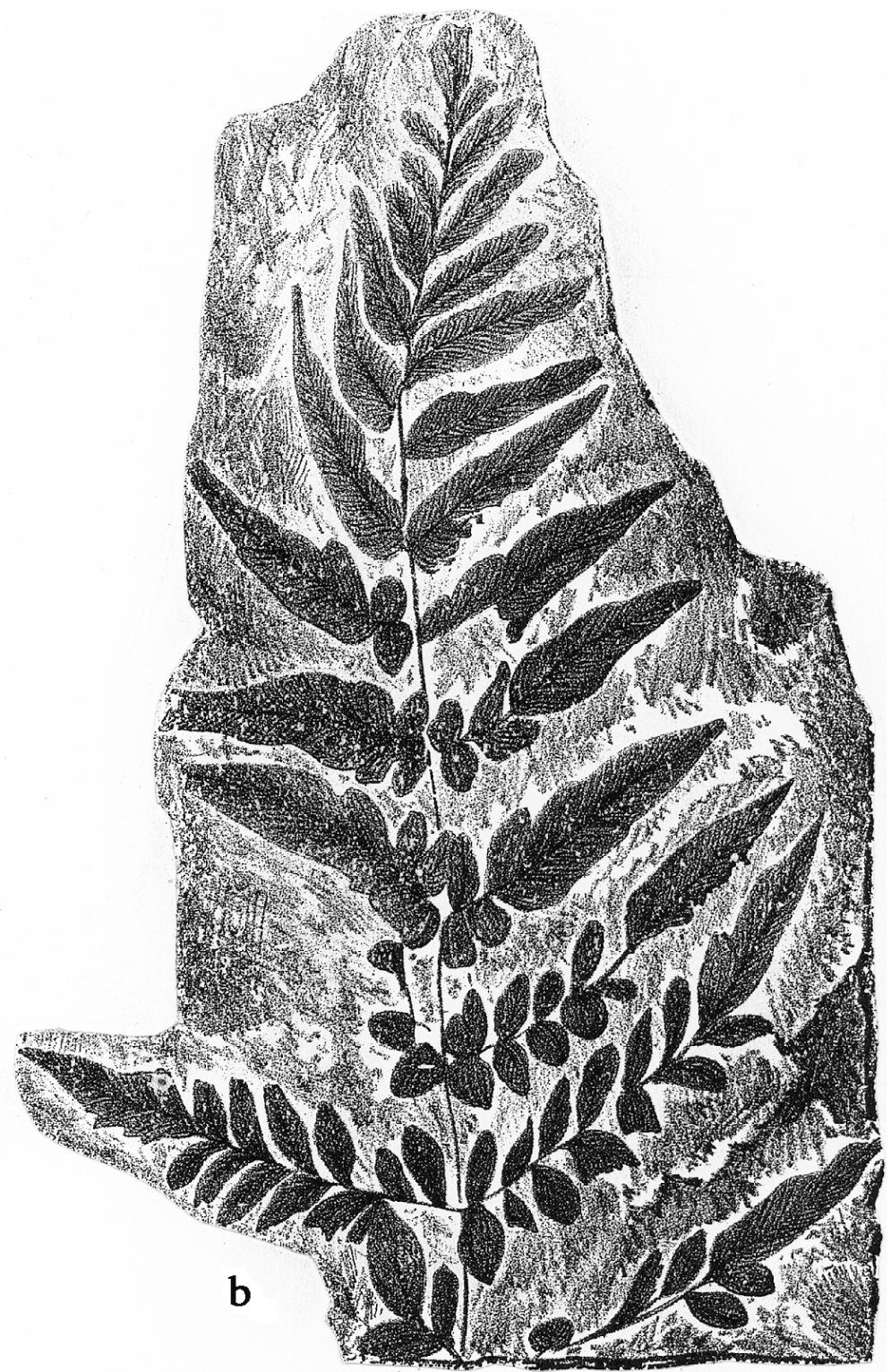

Figure 1. a, Copy of the original illustration of Neuropteris polymorpha Dawson (lectotype) in 1862, pl. XV, fig. 36c. b, Copy of the original drawing of the large pinna of Neuropteris polymorpha by Dawson (1871: pl. XVIII, fig. 212), illustrated photographically by Stopes (1914, 1917: pl. XIV). 
to two thirds, depending on the size of pinnules. Lateral veins thin, thread-like, ascending steeply and relatively straight, abutting obliquely onto the pinnule margin, generally twice forked. Vein density 16-19 veins/cm.

Dawson's (1862: 320) description was as follows "Pinnate or bipinnate. Rachis or secondary rachis irregularly striate. Pinnules varying from round to oblong, unequally cordate at base varying from obtuse to acute. Terminal leaflet ovate, acute, angulated or lobed. Midrib delicate, evanescent. Nervures slightly arcuate, at acute angles with the midrib."

Comparisons: A closely comparable species is Laveineopteris hollandica (Stockmans, 1933) Cleal \& Shute, 1995, so much so that small fragments of these two species can be confused quite easily. Pinnule shape is similar, although there is a tendency towards a more ovoid shape, with bluntly acuminate apices, in Laveineopteris polymorpha. The nervation in both species is characterised by thin, thread-like veins, but Laveineopteris hollandica has a more persistent midrib reaching up to two thirds of the pinnule length, and apparently possesses slightly curved, less straight lateral veins. The vein density (measured on the nervation diagram in Laveine, 1967: fig. 25b) is c. 28 veins/cm in Laveineopteris hollandica and rather less in Laveineopteris polymorpha (16-19). Further comments on Laveineopteris hollandica are provided later on.

Another fairly close comparison is with Laveineopteris tenuifolia (Schlotheim, 1820) Cleal, Shute \& Zodrow, 1990 which shows a similar variation in pinnule size and shape, although with a lesser degree of polymorphism. It also shows a comparable venation which is, however, a little denser, with around 25-28 veins/cm. Laveineopteris tenuifolia is also characterised by a more strongly marked midrib sunken into a somewhat vaulted lamina. Its lateral veins also appear to be less straight, slightly curved. Some of the illustrations in the literature show specimens attributed to Laveineopteris tenuifolia, which are suggestive of Laveineopteris hollandica and Laveineopteris polymorpha, and small fragments may be difficult to tell apart.

Laveineopteris loshii (Brongniart, 1828a) Cleal, Shute \& Zodrow, 1990 is also comparable, but its pinnules commonly show more rounded apices, and less thread-like veins. It also appears that Laveineopteris loshii is not quite as variable in its pinnule morphology as Laveineopteris polymorpha. Bluntly acuminate pinnules as occur in $\mathrm{Neu}$ ropteris polymorpha Dawson, do not seem to be present in Neuropteris loshii, which also appears to have a denser venation, around 30 veins $/ \mathrm{cm}$. Confusion is possible in small fragments showing the smaller kind of pinnules.

\section{Remarks on published remains from the type locality} ("Fern Ledges"): The original illustrations of Neuropteris polymorpha in Dawson (1862) are highly diagrammatic renderings of small pinna and pinnule fragments (Fig. 1a of the present paper). These include a pinna terminal (Dawson, 1862: pl. XV, fig. 36a). A later paper by Dawson
(1871) shows a larger, more complete specimen (also illustrated as a drawing - Fig. 1b of the present paper) which represents the terminal part of a pinna of the penultimate order. The lower part of this specimen shows several side pinnae with terminals of various sizes depending on the position in the major pinna. A comparison with Dawson, 1862: pl. XV, fig. 36a (lectotype) is quite apparent. A photograph of Dawson's 1871 specimen, which is in the Redpath Museum at McGill University in Montreal (Cat. $\mathrm{n}^{\mathrm{o}} 3311$ ), has been published by Stopes (1914: pl. XIV, fig. 35 ), at slightly less than natural size (all Stopes's plates were reduced by the Printer). Whereas Dawson's illustrations are too sketchy to allow the proper identification of his Neuropteris polymorpha, the photographs published by Stopes remove this problem. All specimens are from the Hartt Collection and originate from the "Fern Ledges" in Carleton County, Saint John (New Brunswick) (Hartt collected exclusively from this locality - pers. comm. from R.F. Miller, 31-03-2008). The more useful 1871 specimen is therefore a topotype. A photograph (x 3) of the upper (terminal) and middle parts of the same specimen is reproduced in the present paper (Figs 2-3). Stopes identified this specimen with Neuropteris heterophylla and backed up the identification by figuring a similar specimen from the North of France for comparison (her pl. XV, fig. 36). However, the latter is the form which Laveine (1967) identified with Neuropteris loshii, making the point that Neuropteris heterophylla had been commonly misidentified in Europe. Indeed, he stated that the specimens illustrated as Neuropteris heterophylla in the literature were generally (but not invariably) attributable to Neuropteris loshii. Laveine (1967) placed Dawson's (1871) specimen from the "Fern Ledges", as figured by Stopes (1914: pl. XIV, fig. 35), in the synonymy of Neuropteris loshii, thus admitting the identification between Canadian and French material. However, this seems questionable. Although it is agreed that Neuropteris loshii is closely comparable, and specimens reminiscent of this species have been observed in material from the "Fern Ledges", the generally more bluntly acuminate pinnules of Dawson's specimen are different. Even more different is the fine, thread-like nervation, which is more widely spaced than that of Neuropteris loshii. In fact, the nervation is more reminiscent of Neuropteris hollandica Stockmans, another European species, which is less commonly recorded. The venation of Dawson's (1871) specimen can only be made out with difficulty on the photograph published by Stopes (1914: pl. XIV), but the enlargements figured in the present paper (Figs 2,3) show the venation more clearly albeit not quite as sharply as would be desirable. This is due in part to coating with ammonium chloride; the actual preservation is a little better. An additional, more fragmentary specimen from the "Fern Ledges" was figured by Stopes (1914: pl. XXI, fig. 56) as Neuropteris foliage. Its venation is not clearly visible on the photograph, but apparently fits that of 


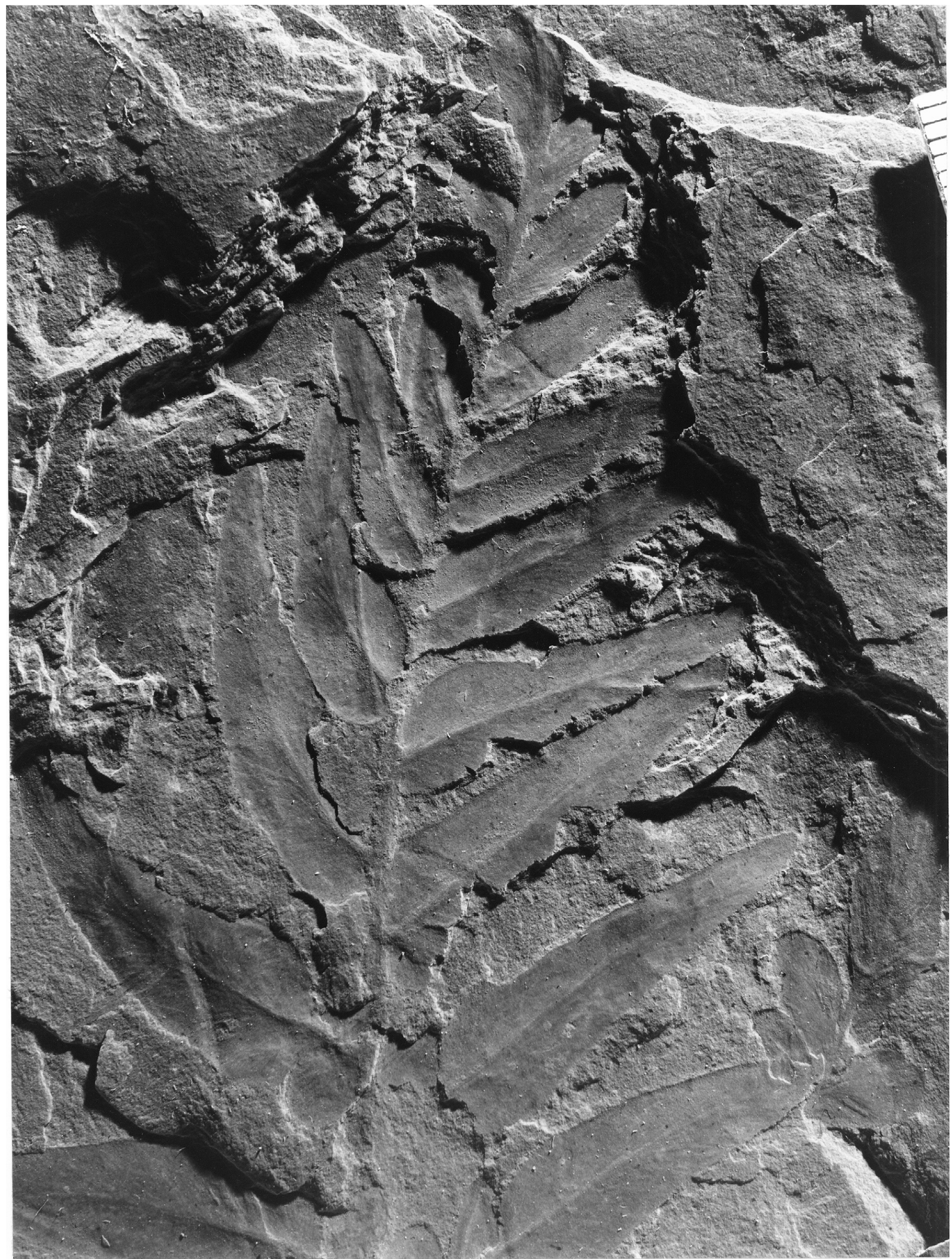

Figure 2. Photographic illustration (x 3) of the upper part of the specimen figured by Dawson (1871: pl. XVIII, fig. 212) and Stopes (1914, 1917: pl. XIV) (Redpath Museum Cat. n $\left.{ }^{\circ} 3311\right)$. 


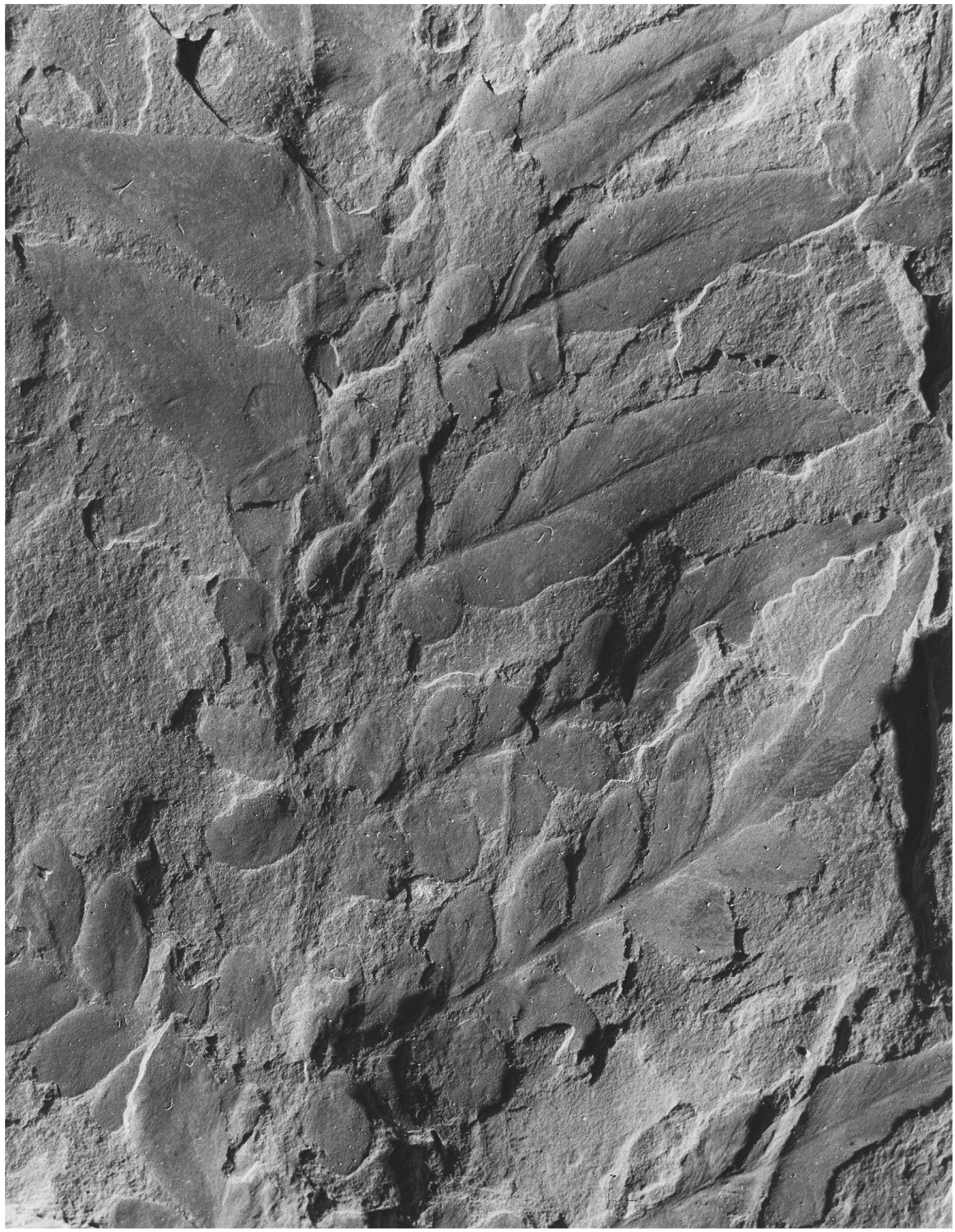


Neuropteris polymorpha. This specimen was attributed to Neuropteris tenuifolia (Schlotheim, 1820) Sternberg, 1825 by Bell (1944: 80). Although this may be regarded as a better approximation than Neuropteris loshii, the present writer prefers to include it with Laveineopteris polymorpha. It is noted that Bell (1944: 81) referred Neuropteris polymorpha Dawson, including the specimens figured as Neuropteris heterophylla by Stopes (1914: pl. XIV, fig. 35; pl. XV, fig. 38) and Neuropteris sp. (Stopes, 1914: pl. $\mathrm{XV}$, fig. 40) to Neuropteris obliqua. The latter is another species of variable pinnule morphology, although characterised by decurrent pinnule bases in the terminal parts of pinnae. This character is less apparent in Laveineopteris polymorpha, which only shows partly adherent pinnule bases in some near-terminal pinna fragments (e.g. Fig. 4d-e). Neuropteris obliqua shows pinnae with large triangular pinnules (forma impar) in the lower part of the frond. Although the variation in pinnule size and shape is also quite large in Laveineopteris polymorpha (probably more so than in other species of Laveineopteris), the forma impar is more extreme in its size variation. This being said, it is true that Neuropteris obliqua has been interpreted quite widely in the literature (not always correctly).

Laveine (1967) accepted that the specimens figured from the "Fern Ledges" by Stopes (1914) on her pl. XV, figs 38, 40 [as Neuropteris heterophylla and Neuropteris sp. (= Nephropteris varia Dawson, 1871), respectively], would belong to Neuropteris obliqua. The present writer concurs. Finally, a single cyclopteroid pinnule figured as Neuropteris eriana (Dawson, 1881) Stopes, 1914 by Stopes (1914: pl. XV, fig. 39) and which she incorporated tentatively with Neuropteris polymorpha (see Stopes, 1914: 62), was also attributed to Neuropteris tenuifolia by Bell (1944: 80). This attribution cannot be accepted. It is likely that this single pinnule should be assigned to Paripteris. The type of the species originally described as Cardiopteris eriana by Dawson (1881: pl. XIII, fig. 18), is too fragmentary for this species to be retained as a viable taxon. Stopes (1914: p. 61-62) did retain this species, as Neuropteris eriana, albeit provisionally.

It is noted that Falcon-Lang \& Miller (2007) mentioned Laveineopteris loshii from the "Fern Ledges", recording it as abundant on some horizons. Judging from the New Brunswick Museum collection (as examined by the present writer), it is likely that their records refer, in the main, to Laveineopteris polymorpha, which is common in the "Fern Ledges". However, the "Fern Ledges" also contain (rarer) remains of Laveineopteris loshii and Neuropteris obliqua (a species which is not recorded as present by Falcon-Lang and Miller). This leaves an element of doubt which can only be resolved by a recount of the specimens studied by these authors, who did not illustrate examples of the different species recorded.

Comments on the general taxonomy: Apart from the fragmentary specimens which may or may not be correctly ascribed to Neuropteris obliqua, a species that does occur in the "Fern Ledges" locality (albeit less commonly), most of the remains identified as Neuropteris polymorpha belong to the general group of Neuropteris tenuifolia and Neuropteris loshii which Cleal et al. (1990) described as Laveineopteris. They defined this genus on the basis of a dichotomous frond structure with the presence of large, orbicular to reniform cyclopterid pinnules attached below the frond dichotomy, imparipinnate pinnae, and anomocytic stomata. Laveine $(1997,2005)$ pointed out that Neuropteris sensu stricto and Laveineopteris were closely similar, particularly with regard to frond structure and the shape of cyclopterid pinnules in the basal part of the fronds. However, in the final analysis, he accepted the genus Laveineopteris on the basis of a marked foliar polymorphism in the basal part of the frond (Laveine, 1997: 178). Laveine (2005) emended the generic description, from which he excluded the cuticular characters. These were regarded as broadly similar for different genera. Although the Neuropteris polymorpha remains, as known from the "Fern Ledges" in New Brunswick, are too fragmentary to show the frond structure as mentioned for Laveineopteris, and cuticular characters cannot be ascertained, the apparent similarity with Laveineopteris tenuifolia suggests that Laveineopteris is involved. Also, only isolated, poorly preserved remains of Cyclopteris are known from the "Fern Ledges". Although possibly attributable to Neuropteris polymorpha, this is by no means certain.

Considerations with regard to the list of synonymy: Apart from the records from the type locality in New Brunswick, Canada, Laveineopteris polymorpha remains have turned up in at least two different places in North America. Arnold (1949) described a Neuropteris saginawensis which is clearly identical to Laveineopteris polymorpha. It is noted that Laveine (1967) placed Arnold's species in synonymy with Neuropteris hollandica, which is closely similar to Laveineopteris polymorpha. One of the specimens figured by Arnold (1949: pl. XXIII, fig. 1) as Neuropteris obliqua from the same locality in the Michigan Basin, also seems referable to Laveineopteris polymorpha. This is the terminal part of a last order pinna, which shows partly adherent pinnule bases in the highest part of the pinna. The ovoid shape of the lateral pinnules in this specimen is characteristic of Laveineopteris polymorpha. Unfortunately, its nervation can only be guessed

Figure 3. Photograph (x 3) of the middle part of the specimen figured by Dawson (1871: pl. XVIII, fig. 212) and Stopes (1914, 1917: pl. XIV). Note partial overlap with Fig. 2. 

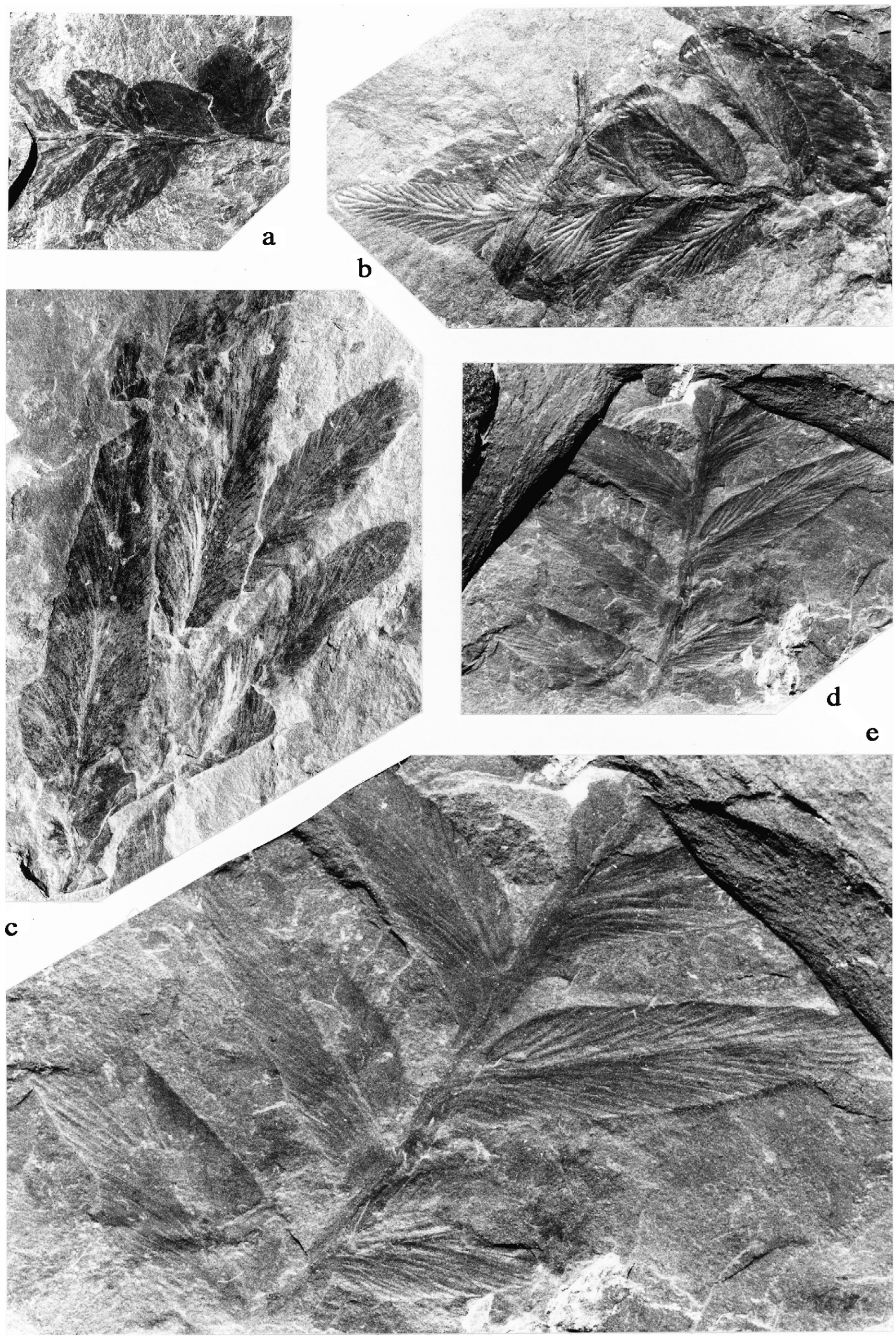
at. Other specimens from North America, which seem referable to Laveineopteris polymorpha, are those figured from West Virginia (Appalachian region) by Jongmans (1937). These specimens (Jongmans, 1937: 407-408; his locality 33) came from the upper Kanawha, i.e. upper Duckmantian/lower Bolsovian, according to Blake et al. (2002). Jongmans (op. cit.) identified these remains with a manuscript species from the upper Duckmantian (ex Westphalian B) of South Limburg, the Netherlands, which he had named Neuropteris latenervosa Jongmans, 1937 (see also Jongmans \& Gothan, 1934). His description of the American specimens fits that of Laveineopteris polymorpha. It is noted that Jongmans (1952: 18) later referred to his species as Neuropteris heterophylla forma latenervosa. Although not exactly a nomen nudum, Jongmans's species or forma fell short of being introduced formally. It is noted that the forma latenervosa as figured by Jongmans (1952) from Djerada, Morocco, probably conforms to Laveineopteris loshii.

Laveineopteris polymorpha also seems to be present in the British Isles where Neuropteris rytoniana Kidston, 1922, as figured and described by Crookall (1959), is an apparent synonym. It is noted that this species was referred to Neuropteris hollandica by Laveine (1967). Crookall (1959) described Neuropteris rytoniana together with Neuropteris formosa Kidston, 1922, both from the same locality, i.e. the Crow Coal, of Duckmantian age, at Ryton in Durham County, England. It is worth noting that both Neuropteris rytoniana and Neuropteris formosa were assigned to Laveineopteris hollandica by Cleal \& Shute (1995). This may well be the correct identification for Neuropteris formosa. It is recalled that Laveineopteris polymorpha and Laveineopteris hollandica are closely comparable.

Crookall (1959) also figured some fragmentary remains of pinnae from the Langsettian (ex Westphalian A) of Lanarkshire, Scotland, under the name of Neuropteris thymifolia Sternberg 1933. This refers to a species originally figured by Lindley \& Hutton (1832) as Neuropteris soretii Brongniart, 1828a, an apparent misidentification as Sternberg (1833) observed. Crookall figured a nervation diagram of the type specimen (op. cit:: text-fig 64B), as drawn by R. Kidston, and noted that the type was too poorly preserved for photographic reproduction. Although Crookall (1959: 105) expressed his doubts about the possibility of distinguishing Neuropteris thymifolia as a viable taxon, he respected Kidston's opinion (in manuscript) and maintained Sternberg's species. Crookall's figures suggest the presence of Laveineopteris polymorpha. Whether or not he identified these fragments correctly as Neuropteris thymifolia is an open question.
Two pinna fragments with relatively large pinnules were figured from the Duckmantian of Derbyshire, England by Crookall (1959: pl. XXXIX, figs 2, 3, 3a) as Neuropteris blissii Lesquereux, 1884. The ovoid pinnule shape with a bluntly acuminate apex suggests Laveineopteris polymorpha and so does the vein pattern. Crookall's identification with Neuropteris blissii is almost certainly incorrect. It seems likely that an additional specimen from the Duckmantian of Ayrshire (Crookall, 1959: pl. XXXIX, fig. 4) also belongs to Laveineopteris polymorpha, but this is less certain. This latter specimen is most comparable to the form recorded as Neuropteris cf. hollandica by Laveine (1967: 161, pl. XXVIII, figs 1-3).

Jongmans (1937: pl. 28, fig. 81) illustrated an associated small Cyclopteris leaflet which he noted as probably belonging to his Neuropteris latenervosa from West Virginia. A similar small Cyclopteris occurs with the material from the "Fern Ledges" in the museum at Saint John (NBMG 7440). There is no guarantee that this isolated specimen actually belongs to Laveineopteris polymorpha, although this is the most common Laveineopteris at this locality. It has not been regarded as worth figuring.

Comments on the specimens illustrated: The most complete specimen known is the terminal part of a pinna of the penultimate order as figured by Dawson (1871: pl. XVIII, fig. 212), and refigured photographically by Stopes (1914, 1917: pl. XIV). Enlargements (x 3) of this specimen are illustrated as Figs 2 and 3 of the present paper. It shows a good deal of variation in pinnule sizes and shapes, ranging from large triangular pinnules through more ovoid ones to smaller, more isodiametric pinnules with rounded apices (as occur in small, hardly individualised side pinnae). These pinnule shapes are quite similar to those occurring in Laveineopteris hollandica, but the venation is different. The midribs of the smaller pinnules are barely visible, occupying only one third to one half of the pinnule length. Lateral veins are steeply inclined, more or less straight and not arched as in Laveineopteris hollandica. Dawson's drawing of this specimen gives a reasonable impression of the vein pattern, although it is only a diagrammatic representation. The photograph published by Stopes does it less justice with regard to the nervation. The enlargements figured in the present paper show the nervation only faintly; however, where the venation is visible it is compatible with that of the more neatly imprinted, smaller fragments illustrated from the same locality (Figs 4-7).

Dawson (1871: 49) gives the locality of his Neuropteris polymorpha as "shales of Carlton near St. John" (New Brunswick). He mentions that the original description

Figure 4. a (NBMG 12053/2), x 3; b (NBMG 10447), x 3; c (NBMG 7387/1), x 3; d (NBMG 12052/2), x 3; e (same as d, x 6). Pinna fragments showing variations in size and shape of pinnules with tendency to tapering sides with lengthening. Note relatively small terminal in (b). Straight, thread-like veins are characteristic. 

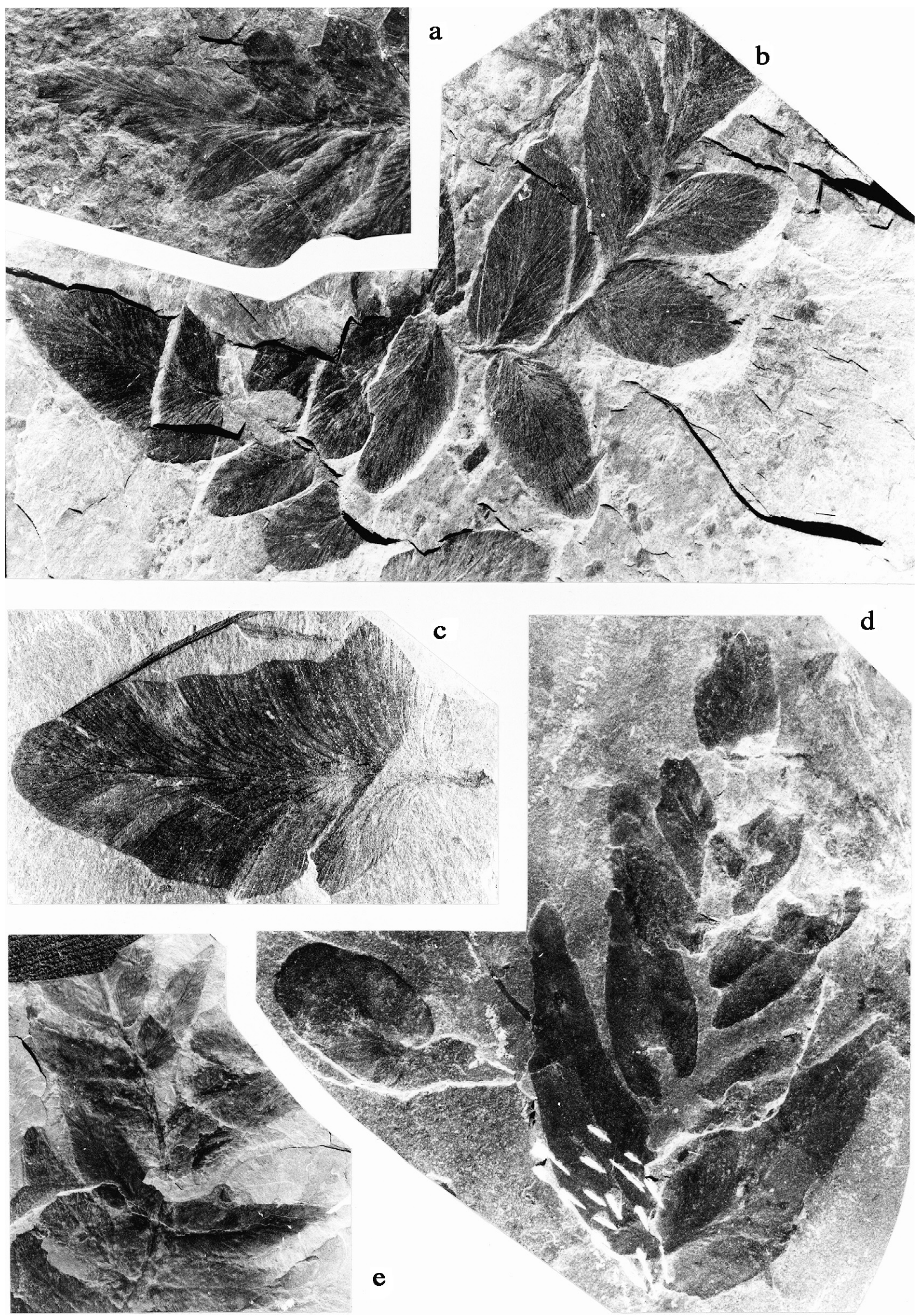

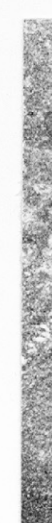


(Dawson, 1862) was based on fragments, but that "A few perfect specimens occur in the collection of Prof. Hartt". It seems that Hartt collected exclusively from the "Fern Ledges" locality at the DeMill property, at about a mile west of Carleton (the old name of a community on the west side of Saint John) (R.F. Miller, pers. comm., 31-032008). All the specimens collected by Hartt were entrusted to Dawson. The later, more complete specimen refigured here at Figs 2-3, thus originated from the same locality as the more fragmentary remains figured by Dawson in 1862 .

Smaller fragments from the "Fern Ledges" at Saint John (New Brunswick), as figured in Figs 4-7, show a wide range of pinnule sizes linked to different shapes. They fully justify the specific epithet of "polymorpha". Pinnule shapes range from elongate, almost subtriangular, to ovoid, but approximating, in some cases, a subcircular shape in the transition between massive, elongate pinnules and side pinnae (compare Fig. 3 and Fig. 7e). Although the pinnules are generally similar to those of Laveineopteris hollandica, the latter is not quite as polymorph, and does not show the bluntly acuminate pinnule apices which are characteristic of Laveineopteris polymorpha. Both species share the thin, thread-like venation, but Laveineopteris polymorpha is characterised by more widely spaced, generally straighter lateral veins.

Occurrence in New Brunswick, Canada: "Fern Ledges" at Saint John, NBMG Catalogue $\mathrm{n}^{\text {os }} 1684 / 1,1684 / 2,1684 / 3,1730$, 2306, 2318, 2319, 7261, 7298, 7387/1, 7525, 7736, 10441, 10447 , 10448/1, 10448/2, 10455, 12044, 12045, 12050/1, 12050/2, 12052/2.

"Fern Ledges", GSC locs. 133 (with Cyclopteris fragment), 134, 146, 351 (6 specimens), 352, 804, 810 (2 specimens), 2254 (11 specimens), 3415.

Rugged Head: GSC loc. 645 (Lepreau Basin).

Gardner's Creek: GSC loc. 701 (3 specimens with cf.), 712 (3 specimens), 794, 799 (near Russell's farm - 1 specimen).

McCoy Head: GSC loc. 793 (1 specimen).

Tynemouth Creek: GSC loc. 802.

NBMG refers to New Brunswick Museum Geology collection at Saint John.

GSC refers to Geological Survey of Canada, Ottawa.

Occurrence in Nova Scotia, Canada: East of Pudsey Point: GSC loc. 3111.

\section{Laveineopteris hollandica (Stockmans, 1933) Cleal \& Shute, 1995}

1915 Neuropteris cf. callosa Lesquereux - Jongmans \& Gothan, p. 165-167, Taf. II, figs 3-6, Taf. III, figs 1-2a.
1928 Neuropteris callosa Lesquereux - Jongmans, p. 21, 49, pl. 14, fig. 1.

? 1932 Neuropteris cf. callosa Lesquereux - Corsin, p. 20, pl. XI, figs 2-5.

* 1933 Neuropteris hollandica Stockmans, p. 31-34, pl. X, figs 1, 1a (holotype).

? 1933 Neuropteris callosa Jongmans \& Gothan (sic) - Crookall, p. 58, pl. VI, fig. 7 (cannot be judged very well from the illustration).

1938 Neuropteris hollandica Stockmans - Renier \& Stockmans in Renier et al., p. 78, p. 15 (plate explanation), pl. 68.

1939 Neuropteris callosa Jongmans \& Kidston ( $\mathrm{sic})(=\mathrm{Neu}$ ropteris hollandica) - Jongmans, p. 46, 48, 66, 67, pl. XXVII, figs 73, 73a? (could also be Laveineopteris tenuifolia), pl. XXIX, figs 79, 79a, 79bis.

? 1944 Neuropteris hollandica Stockmans - Zalessky, p. 285295, Abb. 1-2 (nervation diagrams).

p 1953 Imparipteris (Neuropteris) hollandica Stockmans Gothan , p. 52-53, Taf. 23, figs 1a, 2b, Taf. 26, fig. 2, Taf. 27, fig. 1, ? fig. 2 (comparable to Laveineopteris loshii), Taf. 28, figs 1, 3-4.

p 1959 Neuropteris hollandica Stockmans - Crookall, p. 108110, text-fig. 37 (copy of Jongmans \& Gothan, 1915: Taf. II, fig. 5a, Taf. III, fig. 2a), ? pl. XXXI, figs 4-5 (very fragmentary specimens which have been assigned tentatively to Neuropteris tenuifolia by Laveine, 1967: 159).

1959 Neuropteris formosa Kidston ex Crookall, p. 139-140, text-fig. 63D, pl. LII, figs 1-2 (also according to Cleal \& Shute, 1995: p. 20).

1962 Neuropteris hollandica Stockmans - Stockmans \& Willière, p. 59, 60, 62, 65, 76, 77, 87, pl. D, figs 9-10.

1967 Neuropteris hollandica Stockmans - Laveine, p. 156161, pls XXVI-XXVII.

1967 Neuropteris cf. hollandica Stockmans - Laveine, p. 161-162, pl. XXVIII, figs 1-3.

p ? 1969 Neuropteris hollandica Stockmans - Daber, p. 258, Taf. II, Bild 7 (doubtful, poorly preserved specimen).

1991 Neuropteris hollandica Stockmans - Josten, p. 320321, Taf. 185, figs 1-3.

1995 Laveineopteris hollandica (Stockmans) Cleal \& Shute, p. 20.

\section{Excludenda}

1963 Neuropteris hollandica Stockmans - Josten, p. 96, Taf. 1, figs 1, 1a [= Pseudadiantites sessilis (Roehl, 1868) Gothan, 1929 - also excluded by Laveine, 1967: 159].

p 1969 Neuropteris hollandica Stockmans - Daber, p. 258; Taf. X, Bild 8 (poorly preserved, possibly Neuropteris attenuata Lindley \& Hutton, 1835).

1985 Neuropteris hollandica Stockmans - Gillespie \& Rheams, pl. II, fig. 4 (= Laveineopteris loshii?).

Figure 5. a (NBMG 12045), x 3; b (NBMG 2306), x 3; c (NBMG 12044), x 3; d (NBMG 12050/1), x 3; e (NBMG 7525), x 3. Pinna fragments showing tapering pinnule shapes and relatively small terminals (apical pinnules). (c) is attributed with doubt (mainly on the kind of venation). 
Remarks on the synonymy: Records from the British Isles are reduced to the two specimens figured as Neuropteris formosa by Crookall (1959: pl. LII, figs 1-2). These are from the Duckmantian of County Durham in NE England. It is worth mentioning that Cleal \& Shute (1995) included these specimens in Laveineopteris hollandica, thus verifying the presence of this species in Britain, whilst, on the other hand, it is not included in the distribution charts published by Cleal $(2005,2007)$ for the Pennine Basin in England, and for South Wales, respectively. This seems to indicate its extreme rarity in the British Isles.

Indeed, most records from western Europe are concentrated in the area extending from northern France (Laveine, 1967) through Belgium (Stockmans, 1933; Renier et al., 1938) into South Limburg, Netherlands (Jongmans \& Gothan, 1915; Jongmans, 1928) and western Germany (Josten, 1991).

Records from northeastern Germany are doubtful. Daber (1969) recorded two specimens of Neuropteris hollandi$c a$ from a deep borehole in NE Germany. One of his specimens is accepted with doubt; the other must be rejected.

Jongmans (1939) figured two specimens from the Donbass under the name of Neuropteris callosa (= Neuropteris hollandica). One of the specimens figured (Jongmans, 1939: Taf. XXIX, figs 79, 79a) does indeed suggest Laveineopteris hollandica. This specimen came from the Lotikova Mine, and the horizon is given as $\mathrm{C}_{2}{ }^{6}$. This up- per Westphalian record is stratigraphically anomalous. The other specimen (op. cit.: pl. XXVII, figs 73, 73a) is too fragmentary to be identified reliably.

Two additional records of Neuropteris hollandica from the upper Westphalian of the Donbass (Zalessky, 1944) can only be regarded as doubtful in view of the illustrations which are drawings. Although Zalessky discussed his finds in detail, he was not in a position to publish photographs (he worked from W. Gothan's laboratory in Berlin, and did not have access to his collections which were destroyed in a fire during the Second World War). Zalessky (1944) did publish two well executed drawings, but these fail to convince. Zalessky referred to the records of Neuropteris hollandica from the Donbass by Jongmans (1939), and expressed his disagreement with Jongmans's stratigraphic attribution.

Neuropteris hollandica is listed (but not illustrated) by Fissunenko (in Einor et al., 1996: 97) from the Donbass. Only a single horizon (coal seam k5) is given for what is obviously regarded as a rare species. This locality, which is referred to Lower Moscovian on the chart, is presumably the same as that recorded as K1 by Fissunenko in the Field Guidebook (p. 222) issued for the Donets Basin excursion on the occasion of the VIII International Congress on Carboniferous Stratigraphy and Geology, held in Moscow, 1973. A Westphalian B (= Duckmantian) age is suggested in the Guidebook.

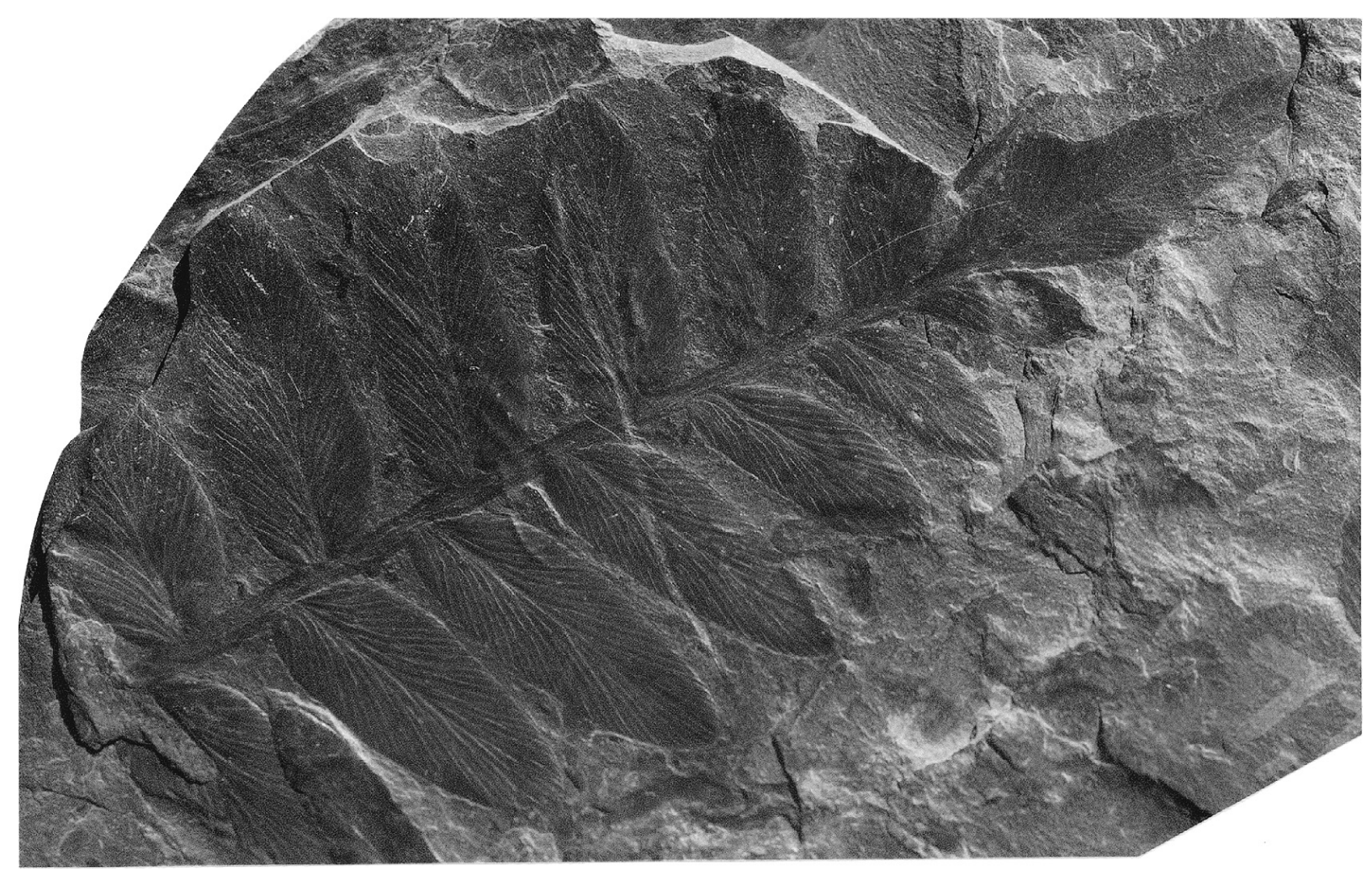

Figure 6. Pinna fragment (NBMG 1730), x 3, showing a rhombic terminal with odontopteroid, subterminal pinnules and, lower down the pinna, relatively large elongate ovoid pinnules which are strikingly similar to Neuropteris saginawensis. 
Discussion: This species is the most closely similar to Laveineopteris polymorpha, and it is possible that a broader interpretation of the intraspecific variation might allow uniting these two taxa described from Canada and western Europe, respectively.

Neuropteris hollandica was introduced by Stockmans (1933) for specimens which Jongmans \& Gothan (1915) had compared with Neuropteris callosa Lesquereux, 1879. At least one of Lesquereux's type specimens (Lesquereux, 1879: pl. XVI, fig. 1) is suggestive of Laveineopteris polymorpha, but the illustrations (drawings) published by Lesquereux are too diagrammatic to allow an identification. A photograph of the same specimen as published by Darrah (1969: pl. 72, fig. 1) does not allow the characters of this species to become apparent. Lesquereux's (1880: 115) description mentions a "thick subcoriaceous texture" which seems to exclude Laveineopteris polymorpha and Laveineopteris hollandica, and the stratigraphic level (Upper Coal strata of Pennsylvania and Ohio) is also quite different.

Stockmans (1933: pl. X, figs 2-5) figured several of Lesquereux's types of Neuropteris callosa photographically (although not his pl. XVI, fig. 1, refigured later by Darrah), and showed that these were inadequate to typify a species, and were certainly different to the remains recorded by Jongmans \& Gothan (1915) from South Limburg. Darrah (1969: 24, 97) provided a brief description of Neuropteris callosa, which he regarded as a usable species, and figured a "paratype" (op. cit.: pl. 72, fig. 1). This was the specimen figured by Lesquereux (1879: pl. XVI, fig. 1). Unfortunately, as Darrah himself admitted, this photograph is too indistinct for a proper identification of Neuropteris callosa. This species should probably be regarded as species dubia. It has been generally ignored.

After proving that Neuropteris callosa had been identified incorrectly from South Limburg, Stockmans (1933) proceeded to describe the European taxon as Neuropteris hollandica. This was typified by a single specimen (holotype) from the Duckmantian (ex Westphalian B) of South Belgium, near Charleroi. This single specimen (terminal part of a last order pinna) could well be mistaken for Laveineopteris polymorpha, although slight differences may be observed in the vein pattern. Stockmans (1933: 32) mentioned a thin midrib reaching up to close the pinnule apex, and lateral veins which are slightly curved. The holotype of Neuropteris hollandica seems quite insufficient to characterise a frond species with intraspecific variability.

A fuller description was provided by Laveine (1967), who dealt with material from the North of France, in the continuation of southern Belgium. If the documentation in Laveine (1967: 156-161, pls XXVI-XXVII) is taken as properly representing the species introduced by Stockmans (which is likely but not entirely certain in view of the fragmentary nature of the holotype), there are differences with regard to Laveineopteris polymorpha. These differences, which are possibly minor, have been noted already under "Comparisons".

It may be useful to transcribe Laveine's description in English translation: "Elongate, oval to triangular pinnules which are slightly arched, alternate, with a cordate base. Pinnules close to pinna terminals adherent to the rachis by a small part of the base. Apical pinnules larger than adjacent pinnules, and very elongate deltoid. Thin nervation. Midrib distinct in three fourths of the pinnule length. Lateral veins well spaced out, issuing at a narrow angle and slightly arched, often a little flexuous, dichotomising twice to four times and arriving quite obliquely to the pinnule border. The lateral veins are well marked. Last order pinnae imparipinnate, of elongate oval shape. Rachis longitudinally striate and generally rather wide.'

One might add that the nervation density as measured on the nervation diagram provided by Laveine (1967: 157, fig. $25 \mathrm{~b}$ ) comes to c. 28 veins $/ \mathrm{cm}$ on the pinnule border.

Similar remains of Neuropteris hollandica were recorded from NW Germany by Josten (1991: 320-321, Taf. 185, figs 1-3). His nervation diagram (op.cit.: Abb. 206) shows several times forked nervules with a nervation density of c. $23 \mathrm{veins} / \mathrm{cm}$. The ovoid shape of the pinnules is characteristic, as is the distinctly marked venation consisting of a thin midrib and thread-like lateral veins.

The documentation provided by Laveine (1967) and Josten (1991) from a single sedimentary basin in western Europe (to which the coalfield at Charleroi, Belgium, belongs as well) allows the rare species, Laveineopteris hollandica, to be identified without difficulty. This species is subtly different from Laveineopteris polymorpha from North America, which shows generally more acuminate pinnules, with a less persistent midrib and straighter lateral veins which are less repeatedly dichotomous and a little more widely spaced.

Still, the list of synonymy published by Laveine (1967) contains a couple of references to species recorded from North America and the British Isles (i.e. Neuropteris saginawensis and Neuropteris rytoniana) which the present writer prefers to assign to Laveineopteris polymorpha. It thus appears that Laveineopteris hollandica and Laveineopteris polymorpha are sufficiently close to be confused in such cases where only fragmentary remains are available. An effort has been made to compose a list of synonymy for Laveineopteris hollandica. This may allow drawing certain conclusions with regard to the stratigraphic ranges and the geographical distribution of the two species involved. An updated list of synonymy is provided.

Stratigraphic and geographic distribution: The two similar (but not quite identical) species, Laveineopteris polymorpha and Laveineopteris hollandica, share the same stratigraphic distribution. This refers to the lower Westphalian, i.e. Langsettian and Duckmantian substages. The records of Laveineopteris polymorpha are too sparse for 

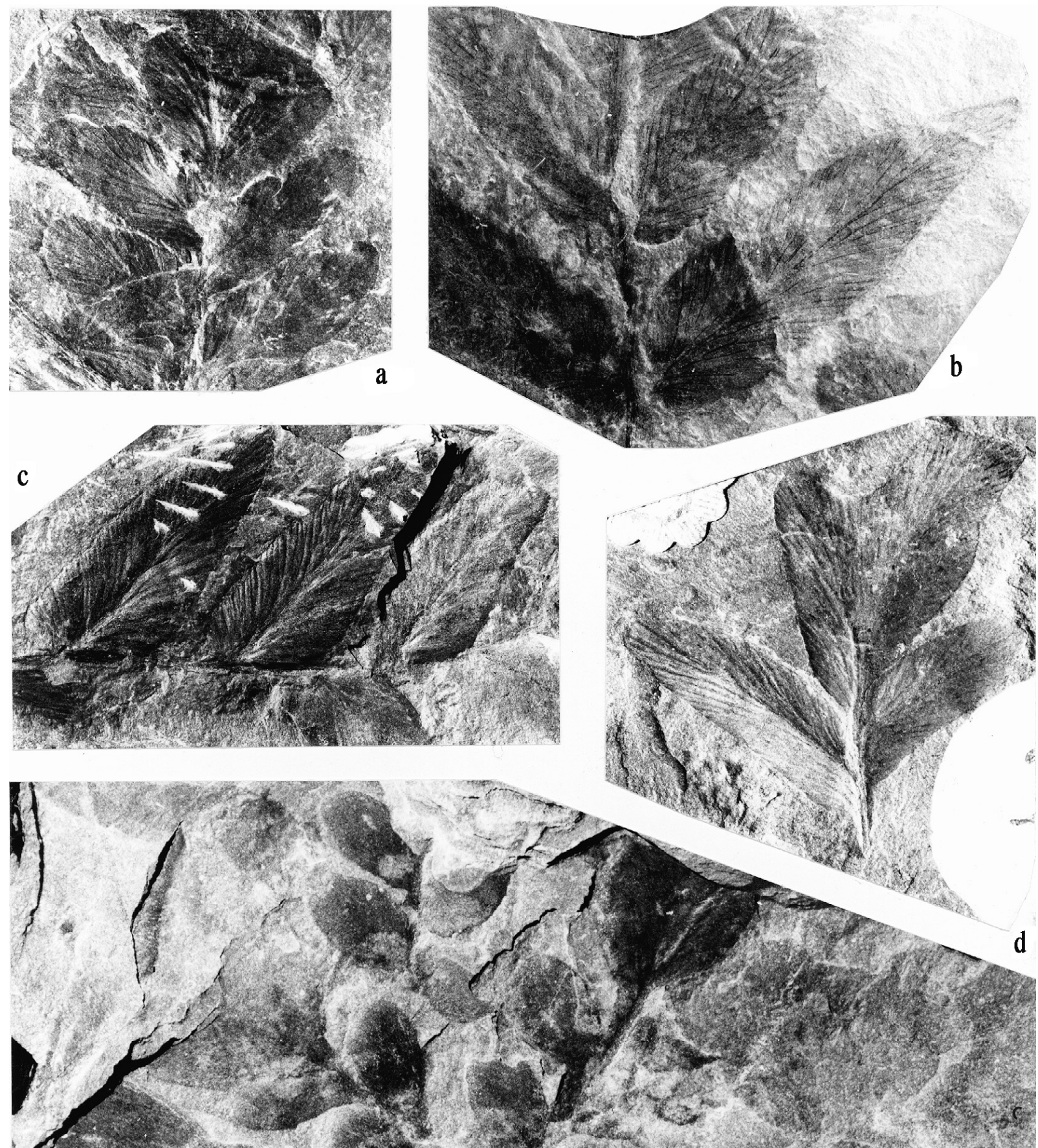

(
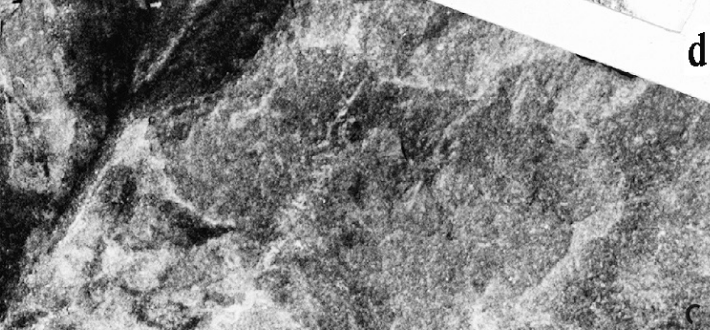

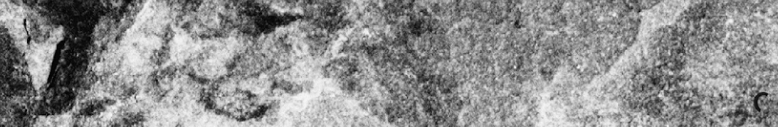

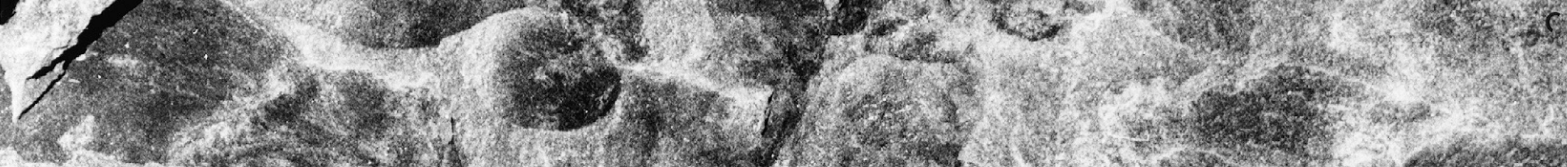

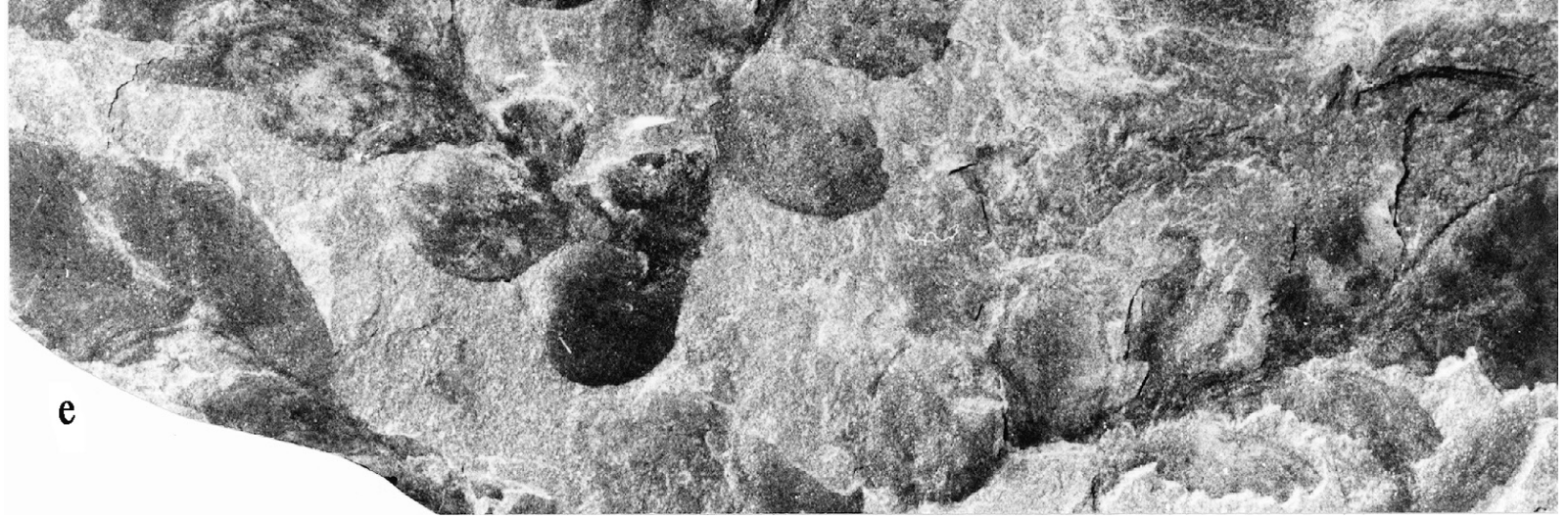


further precision. Laveine (1967: range chart on p. 299) shows Laveineopteris hollandica as occurring mainly in the Duckmantian (ex Westphalian B) but with occasional finds in the highest Langsettian. Josten (1991, 2005: range chart) also shows the first occurrence of Laveineopteris hollandica in the highest Langsettian, but extends its range into the upper Bolsovian, where its records are sparser however (op. cit.). The figured specimens from western Germany are both from the Duckmantian of the Ruhr District.

It may be that the records of Laveineopteris polymorpha (including its synonyms Neuropteris saginawensis and Neuropteris rytoniana) are too sparse to allow a proper appreciation of the geographical distribution of this species. However, all the known records pertain to North America and the British Isles. On the other hand, there are no reliable records of Laveineopteris hollandica from North America, and almost none from the British Isles (where it has been ignored in the distribution charts published by Cleal, 2005, 2007). Indeed, most of the well documented records are from the belt of coal-bearing strata extending from the North of France, through Belgium and Netherlands Limburg into western Germany. Its geographic distribution possibly extends eastwards into NE Germany (Daber, 1969) and the Donbass, South of the Russian Platform. Although sparsely illustrated (Jongmans, 1939), Laveineopteris hollandica does seem to occur in the Donbass. One would have expected this species to have been found also in the well sampled strata of the Upper Silesian Basin (including the Ostrava-Karviná area of Moravia in the Czech Republic), which lies in the intermediate area, but it seems that no published records of Laveineopteris hollandica exist for this area.

It is noted that no records exist of either Laveineopteris polymorpha or Laveineopteris hollandica from the well sampled lower Westphalian strata in different parts of the Iberian Peninsula. Laveineopteris does occur in both NW Spain (Cantabrian Mountains) and SW Spain (Peñarroya Coalfield), but the species recorded, Laveineopteris resobae (Cleal, 1981) Cleal \& Shute, 1995 and Laveineopteris guadiatensis (Wagner, 1983) Cleal \& Shute, 1995 are close to Laveineopteris tenuifolia.

\section{ACKNOWLEDGEMENTS}

Thanks are due to John Utting, of the Geological Survey of Canada, for putting into place a project to revise the upper Namurian and lower Westphalian floras of the Maritime Provinces in the context of a palynological and stratigraphic investigation of the relevant strata in Nova Scotia and New Brunswick. Ran- dall Miller, Curator at the New Brunswick Museum, Saint John, has allowed access to the collections in his care, as well as being helpful in many ways. His pertinent comments on the history of the collections are particularly appreciated. Jean Dougherty, Curator of the Collections at the Geological Survey of Canada, at Ottawa, has also been kind and helpful as always. Both institutions mentioned provided some funding which allowed for travel and maintainance. Two successive grants from the G.F. Matthew Fund are acknowledged in particular. The kindness of Ingrid Birker, Curator of the Redpath Museum at McGill University, is also acknowledged with pleasure, as is permission to illustrate a specimen from the Dawson Collection at Montreal. This was photographed by Robert Kelly in Ottawa (Geological Survey). The helpful comments of two referees, Jean-Pierre Laveine and Henk van Amerom, allowed further precision. JeanPierre's critical comments regarding the differences between Laveineopteris polymorpha and L. hollandica, two similar species which the present writer was inclined to regard as one and the same, were fully accepted for the final version of this paper. His expert opinions are gratefully acknowledged. Carmen Álvarez-Vázquez is thanked for aid in the production of the manuscript as well as stimulating discussion.

\section{REFERENCES}

Alison, D. \& Carroll, R. 1972. Catalogue of the Type and Figured Specimens, Fossil Vertebrates, Invertebrates and Plants in the Redpath Museum, McGill University. Redpath Museum, McGill University, Montreal, 1-173.

Arber, E.A.N. 1914. On the fossil floras of the Wyre Forest, with special reference to the geology of the coalfield and its relationships to the neighbouring coal measure areas. Philosophical Transactions Royal Society of London, (B), 204, 363-445.

Arnold, C.A. 1949. Fossil Flora of the Michigan Coal Basin. Contributions Museum of Paleontology, University of Michigan, VII (9), 131-269.

Barnard, P.D.W. \& Long, A.G. 1975. Triradioxylon - a New Genus of Lower Carboniferous Petrified Stems and Petioles together with a Review of the Classification of Early Pterophytina. Transactions Royal Society of Edinburgh, 69 (10), 231-249.

Bell, W.A. 1944. Carboniferous rocks and fossil floras of northern Nova Scotia. Canada Department of Mines and Resources, Mines and Geology Branch, Geological Survey, Memoir 238, 1-119, pls I-LXXIX.

Blake, B.M. 1997. Revised Lithostratigraphy and Megafloral Biostratigraphy of the New River and Kanawha Formations (Pottsville Group: Lower and Middle Pennsylvanian) in Southern West Virginia. M. Sc. Thesis West Virginia University, Morgantow, 1-149, pls 2-11 (unpublished).

Blake, B.M., Cross, A.T., Eble, C.F., Gillespie, W.H. \& Pfefferkorn, H.W. 2002. Selected plant megafossils from

Figure 7. a (NBMG 10455), x 3; b (NBMG 7525, same as Fig. 5e, x 6); c (NBMG 7736), x 3; d (NBMG 7261), x 3; e (NBMG 12050/2), x 3. Pinna fragments showing variations in size and shape, (e) being least characteristic (with rounded pinnules reminiscent of Laveineopteris loshii). 
the Carboniferous of the Appalachian region, eastern United States: geographic and stratigraphic distribution. In: Carboniferous and Permian of the World, Proceedings XIV International Congress Carboniferous and Permian Stratigraphy, Calgary, Alberta 1999 (Eds. L.V. Hills, C.M. Henderson \& E.W. Bamber). Canadian Society of Petroleum Geologists, Memoir 19, 259-335, pls I-XXXV.

Brongniart, A. 1822. Sur la classification et la distribution des végétaux fossiles en général, et sur ceux des terrains de sédiment supérieur en particulier. Mémoires Musée d'Histoire naturelle, Paris, 8, 203-348.

Brongniart, A. 1828a. Prodrome d'une Histoire des Végétaux fossiles. F.G. Levrault, Paris, Strasbourg, 1-225.

Brongniart, A. 1828b-1838. Histoire des végétaux fossiles, ou Recherches botaniques et géologiques sur les végétaux renfermés dans les diverses couches du globe. Texte: I (1828-1837) - 1 (1828): i-xii, 1-80; 2 (1828): 81-136; 3 (1829): 137-168; 4 (1830): 169-208; 5 (1831): 209-248; 6 (1831): 249-264; 7 (1833): 265-288; 8 (1834): 289-312; 9 (1834): 313-316; 10 (1836): 337-368; 11 (1837): 369-416; 12 (1837): 417-488. II (1837-1838) - 13 (1837): 1-24; 14 (1838): 25-56; 15 (1838): 57-72; Atlas: I - Pls 1-166; II Pls 1-30. Facsimile Edition W. Junk, Berlin (1915).

Cleal, C.J. 1981. A new species of Neuropteris from the middle Westphalian of Palencia. Estudios Geológicos, 37, 77-82.

Cleal, C.J. 2005. The Westphalian macrofloral record from the cratonic central Pennines Basin, UK. Zeitschrift der deutschen Gesellschaft für Geowissenschaften, 156, 387401.

Cleal, C.J. 2007. The Westphalian-Stephanian macrofloral record from the South Wales Coalfield, UK. Geological Magazine, 144 (3), 465-486.

Cleal, C.J. \& Shute, C.H. 1995. A synopsis of neuropteroid foliage from the Carboniferous and Lower Permian of Europe. Bulletin Natural History Museum, Geology Series, 51 (1), 1-52.

Cleal, C.J., Shute, C.H. \& Zodrow, E.L. 1990. A revised taxonomy for Palaeozoic neuropterid foliage. Taxon, 39 (3), 486-492.

Corsin, P. 1932. Guide paléontologique dans le Terrain houiller du Nord de la France. Travaux et Mémoires de l'Université de Lille (Musée Houiller), Albums 5, 1-44, pls I-XL.

Crookall, R. 1933. Contributions to the Geology of the Kent Coalfield. Summary of Progress of the Geological Survey of Great Britain and the Museum of Practical Geology for the Year 1932, II, 44-68, pls V-VII.

Crookall, R. 1959. Fossil Plants of the Carboniferous Rocks of Great Britain (Second Section). Memoirs Geological Survey of Great Britain. Palaeontology, IV (2), 85-216, pls XXV-LVIII.

Daber, R. 1969. Paläobotanische Hinweise auf eine paralisch beeinflußte Oberkarbon-Senke im tieferen Untergrund Nordostdeutschlands, II (Teil 1). Geologie, 18 (3), 253297, Tafn I-XIV.

Darrah, W.C. 1969. A critical review of the upper Pennsylvanian floras of eastern United States with Notes on the
Mazon Creek flora of Illinois. Privately Printed Monograph, 220 pp., pls 1-80. Library of Congress Catalog Card Number 74-113602.

Dawson, J.W. 1862. On the Flora of the Devonian Period in North-Eastern America. Quarterly Journal Geological Society of London, XVIII, 296-330, pls XII-XVII.

Dawson, J.W. 1868. Acadian Geology. The Geological Structure, Organic Remains, and Mineral Resources of Nova Scotia, New Brunswick, and Prince Edward Island. (2 $2^{\text {nd }}$ edition). Macmillan and Co., and Montreal, William Foster Brown \& Co, London, 694 pp.

Dawson, J.W. 1871. The Fossil Plants of the Devonian and Upper Silurian Formations. Geological Survey Canada, Report, 92 pp., pls I-XX.

Dawson, J.W. 1881. Notes on New Erian (Devonian) Plants. Quarterly Journal Geological Society of London, XXXVII, 299-308, pls XII-XIII.

Dawson, J.W. 1882. The fossil plants of the Erian (Devonian) and upper Silurian formations of Canada. Geological Survey of Canada, 95-142, pls XXI-XXIV.

Dawson, J.W. 1888. The Geological History of Plants (reissued in 1905). London, 290 pp. (non vide).

Einor, O.L., Nemirovskaya, T.I. \& Solovieva, M.N. (eds) 1996. European part of the USSR. In: The Carboniferous of the World. III. The former USSR, Mongolia, Middle Eastern Platform, Afghanistan, \& Iran (Eds R.H. Wagner, C.F. Winkler Prins \& L.P. Granados). IUGS Publication 33. Instituto Tecnológico GeoMinero de España, Madrid, and Nationaal Natuurhistorisch Museum, Leiden, 23-122.

Falcon-Lang, H.J. \& Miller, R.F. 2007. Palaeoenvironments and palaeoecology of the Early Pennsylvanian Lancaster Formation ("Fern Ledges") of Saint John, New Brunswick, Canada. Journal of the Geological Society, London, 164, 945-957.

Gillespie, W.H. \& Rheams, L.J. 1985. Plant megafossils from the Carboniferous of Alabama, U.S.A. Dixième Congrès International de Stratigraphie et de Géologie du Carbonifère, Madrid 1983, Compte Rendu 2, 191-202, pls I-III.

Göppert, H.R. von 1841-1848. Die Gattungen der fossilen Pflanzen verglichen mit denen der Jetztwelt und durch Abbildungen erläutert. Lief. I-II (1841): 1-120, Tafn I-XVIII; Lief. III-IV (1842): Tafn I-XVIII; Lief. V-VI (1848): Tafn I-XX. Bonn (non vide).

Gothan, W. 1929. Die Steinkohlenflora der westlichen paralischen Carbonreviere Deutschlands. Arbeiten aus dem Institut für Paläobotanik und Petrographie der Brennsteine, I (1), 1-48, Tafn 1-16. Preußische Geologische Landesanstalt, Berlin.

Gothan, W. 1953. Die Steinkohlenflora der westlichen paralischen Steinkohlenreviere Deutschlands, 5. Beiheft zum Geologischen Jahrbuch, 10, 83 pp., Tafn 1-44.

Jongmans, W.J. 1928. Stratigraphie van het Karboon in het algemeen en van Limburg in het bijzonder. Geologisch Bureau voor het Nederlandsche Mijngebied te Heerlen, Mededeeling 6, 1-50, pls 1-17.

Jongmans, W.J. 1937. Comparison of the floral succession in the Carboniferous of West Virginia with Europe. Compte Rendu $2^{e}$ Congrès pour l'avancement des études 
de Stratigraphie Carbonifère, Heerlen 1935, I, 393-422, pls 11-36.

Jongmans, W.J. 1939. Die Kohlenbecken des Karbons und Perms im USSR und Ost-Asien. Geologische Stichting, Geologisch Bureau voor het Mijngebied te Heerlen, Jaarverslag 1934-1937, 15-192, Tafn I-XL.

Jongmans, W.J. 1952. Note sur la flore du Terrain carbonifère de Djerada (Maroc oriental). Notes et Mémoires, Service Géologique, Maroc, 91, 1-27, pls I-XXI.

Jongmans, W.J. \& Gothan, W. 1915. Bemerkungen über einige der in den niederländischen Bohrungen gefundenen Pflanzen. Anhang zu Jongmans, W.J. Paläobotanischstratigraphische Studien im Niederländischen Carbon nebst Vergleichen mit umliegenden Gebieten. Archiv für Lagerstättenforschung, 18, 186 pp., Tafn I-VI.

Jongmans, W.J. \& Gothan, W. 1934. Florenfolge und vergleichende Stratigrafie des Karbons der östlichen Staaten Nord-Amerika's. Vergleich mit West-Europa. Geologisch Bureau Heerlen, Jaarverslag, 1933, 17-44.

Josten, K.H. 1963. Die Makroflora des Oberkarbons der Bohrung Münsterland 1. Fortschritte Geologie Rheinland und Westfalen, 11, 95-98, Taf. 1.

Josten, K.H. 1991. Die Steinkohlen-Floren Nordwestdeutschlands. Fortschritte Geologie Rheinland und Westfalen, 36, Text-Band: 1-434, 29 Tab.; Tafel-Band.: 1-220.

Josten, K.H. 2005. Florenstratigraphie des Oberkarbons in Nordwestdeutschland. Courier Forschungsinstitut Senckenberg, 254, 119-132.

Kidston, R. 1893. On the Fossil Plants of the Kilmarnock, Galston, and Kilwinning Coal Fields, Ayrshire. Transactions Royal Society of Edinburgh, XXXVII (pt. II-No16), 307-358, pls I-IV.

Kidston, R. 1922. Lists of Fossil Plants from the Upper Carboniferous Rocks of the Northumberland and Durham Coalfield and their bearing on the Age of the Coalfield. Summary of Progress of the Geological Survey for 1921, Appendix II, 129-145.

Laveine, J.-P. 1967. Contribution à l'étude de la flore du Terrain Houiller. Les Neuroptéridées du Nord de la France. Études géologiques pour l'Atlas de Topographie souterraine, Service Géologique Houillères du Bassin du Nord et du Pas-de-Calais. I.- Flore fossile, 5, Texte: 1-344, pls A-H, J-K, M-P; Atlas: pls I-LXXXIV.

Laveine, J.-P. 1997. Synthetic analysis of the Neuropterids. Their interest for the decipherment of Carboniferous palaeogeography. Review of Palaeobotany and Palynology, 95, 155-189.

Laveine, J.-P. 2005. The Cyclopteris of Laveineopteris (Late Carboniferous pteridosperm). Facies and facts: methodological and taxonomical implications. Revue de Paléobiologie, Genève, 24 (2), 403-487, pls I-XXIII.

Lesquereux, L. 1879-1884. Description of the Coal Flora of the Carboniferous Formation in Pennsylvania and throughout the United States. Second Geological Survey of Pennsylvania. Report of Progress, Atlas (1879), pls A, B; pls I-LXXXV. Text - I (1880): 1-354; II (1880): 355-694, pls LXXXVI, LXXXVII; III (1884): 695-977, pls LXXXVIII-CXI.
Lindley, J. \& Hutton, W. 1831-1837. The Fossil Flora of Great Britain; or, Figures and Descriptions of the Vegetable Remains found in a Fossil State in this Country. James Ridgway and Sons, London, I (1831-1833) - 1831: 1-47, Pls 1-14; 1832: 48-166, Pls 15-59; 1833: 167-224, Pls 60-79; II (1833-1835) - 1833: 1-56, Pls 80-99; 1834: 57-156, Pls 100-137; 1835: 157-208, Pls 138-156; III (1835-1837) - 1835: 1-72, Pls 157-176; 1836: 73-122, Pls 177-194; 1837: 123-208, Pls 195-230.

Matthew, G.F. 1910. The Oldest Silurian Flora. Bulletin of the Natural History Society of New Brunswick, VI (II), 241-249.

Meyen, S.V. 1984. Basic Features of Gymnosperm Systematics and Phylogeny as Evidenced by the Fossil Record. The Botanical Review, 50 (1), 1-112.

Renier, A., Stockmans, F., Demanet, F. \& Straelen, V. van. 1938. Flore et Faune houillères de la Belgique. Introduction à l'étude paléontologique du terrain houiller. Musée royal d'Histoire naturelle de Belgique, Bruxelles, Texte: 1-317; Planches: 1-49, pls 1-144.

Roehl, D. von 1868. Fossile Flora der Steinkohlen-Formation Westphalens einschliesslich Piesberg bei Osnabrueck. Palaeontographica, XVIII, 1-6, 1-191, Tafn I-XXXII.

Schlotheim, E.F. von 1820. Die Petrefactenkunde auf ihrem jetztigen Standpunkte, durch die Beschreibung seiner Sammlung versteinerter und fossiler Überreste des Thierund Pflanzenreichs der Vorwelt erläutert. Gotha, i-lxii (Einleitung), 1-437, Tafn I-XXXVI (Nachträge in 1822; i-xi, 100 pp. und 1823, 114 pp.).

Seward, A.C. 1898-1919. Fossil Plants. Cambridge Biological Series, Cambridge University Press, London, I (1898): 1-452, figs 1-111; II (1910): 1-624, figs 112-376; III (1917): 1-656, figs 377-629; IV (1919): 1-543, figs 630-818.

Sternberg, K. von 1820-1838. Versuch einer geognostischbotanischer Darstellung der Flora der Vorwelt, I (18201825) 1 (1820): 1-24, Tafn I-XIII; 2 (1823): 1-33, Tafn XIV-XXVI; 3 (1824): 1-40, Tafn XXVII-XXXIX; 4 (1825): 1-48, Tafn XL-LIX, Tafn A-E. II (1833-1838) - 5/6 (1833): 1-80, Tafn I-XXVI; 7/8 (1838, Presl): 81-220, Tafn I-LXVIII, Tafn A, B (incl. Corda: Skizzen zur vergleichenden Phytotomie vor- und jetztweltlicher Pflanzenstämme, I-LXXI).

Stockmans, F. 1933. Les Neuroptéridées des bassins houillers belges (première partie). Mémoires Musée Royal d'Histoire Naturelle de Belgique, 57, 1-61, pls I-XVI.

Stockmans, F. \& Willière, Y. 1962. Commentaire Paléobotanique. Quelques végétaux du Westphalien B du Massif du Borinage (Concession de l'Ouest de Mons). In: Lambrecht, L., Lhoest, A., Piérart, P. \& Willière, Y. Observations sur la Paléontologie et la Stratigraphie du Westphalien B moyen et inférieur dans la partie occidentale du Massif du Borinage. Publication 5, Centre National de Géologie Houillère, Bruxelles, 45-97, pls A-D.

Stopes, M.C. 1914. The "Fern Ledges" Carboniferous Flora of St. John, New Brunswick. Geological Survey Canada, Memoir 41 (38 of Geological Series), 1-142, pls I-XXV (all slightly reduced in the printing) (traduction française 
1917. Flore carbonifère des "assises à fougères" de SaintJean, Nouveau-Brunswick. Geological Survey of Canada, Memoir 41)

Wagner, R.H. 1983. Neuropteris guadiatensis, a new species from the Westphalian B of the Peñarroya-Belmez coalfield in the province of Córdoba, S.W. Spain. In: Contributions to the Carboniferous Geology and Palaeontology of the Iberian Peninsula (ed. M.J. Lemos de Sousa). Universidade do Porto, Faculdade de Ciências, Mineralogia e Geologia, 93-99.

Zalessky, M.D. 1944. Über den Fund der Neuropteris hollan- dica Stockmans im Donezbecken und über die stratigrafische Bedeutung dieser Art, neben der Art Neuropteris (Mixoneura) ovata Hoffmann, bei der Gegenüberstellung des Karbonquerschnittes des Donezbeckens mit dem niederrhein-westfälischen Karbon. Monatshefte Neues Jahrbuch für Mineralogie, Geologie und Paläontologie, Abt. B, Geologie-Paläontologie, Jahrgang, 1944, 285-295.

Manuscrito recibido: 4 de Febrero, 2008 Manuscrito aceptado: 22 de Julio, 2008 